\title{
「水の都」新潟における掘割の喪 失過程について
}

松本智史 一 -1 越澤 明 一 2

キーワード :

掘割, 信濃川, 新潟市

Keywords :

Canal, The Shinano River, Niigata City

\section{A STUDY ON THE PROCESS OF RECLAMATION OF THE CANALS IN FORMER CANAL CITY NIIGATA}

Satoshi MATSUMOTO $-* 1$ Akira KOSHIZAWA — $* 2$

Once, Niigata was the Canal City. The canals covered the town and rowboats were coming and going. However, these canals were filled in at the time of the rapid economic growth of the Showa 30s. Although the reclamation of the canals and the Shinano River have an important meaning in Niigata's city formation, there is no detailed research, studies nor data on this process. In this research, the process in which the canals are lost from Niigata is clarified toward the revitalization of the canals expected in the future.

\section{1.はじめに}

新潟市は信濃川の河口に位置し、古くから港町として発展し てきた。そして新潟の町は「水のにいがた八千八川」と唄われ るように、縦横に走る掘割と柳並木のある「水の都」であった。 新潟の人々の生活と信濃川・掘割を利用した水運、舟運は哚い つながりを持っていた。しかし、昭和になると掘割は埋め立て られ、信濃川も水面の約 3 分の 2 を埋め立てられてしまう。そ のため、現在の新潟市の市街地において水の都としての新潟を 感じることのできる場所は少ない。

新潟の都市形成において重要な意味をもつ掘割の埋め立てや 信濃川の埋め立てであるが、これらの経緯を都市計画の観点か らまとめた行政資料、出版物、研究論文は存在しない。

約 1 年前に新潟の掘割についての講演会が催され、掘割再生 に向けての機運も高まり始めている。そこで本研究は、新潟の 町から掘割が失われていく過程を資料を発掘し確認することに より、都市計画の観点からまとめ直すものとする。掘割再生が 可能かどうかは別として、歷史を活かしたまちづくりは今後の 新潟の都市計画において一つの課題であり、その資料としても 本研究は意味を持つ。

研究方法は市史・新聞などの史料による歴史調查、行政資料・ ヒアリング注1) による調査・分析によっている。

\section{2、掘割の形成と都市計画}

\section{2-1 掘割の形成}

江戸時代、新潟の町は港町として大きく発展する。まず、長 岡藩主・堀直部により港町としての基礎が築かれた。元和 2 (1616) 年、直咅は諸々の税を免除し、新潟の自由貿易港として の発展を図った。さらに元和 3 (1617) 年に発布された「覚」に おいて新潟の町の移転と港町としての計画的な整備を指示し、 短期間の内にこの整備が行われた。

その後、町域の拡大に伴い無秩序に発展してきた町並みの整 理を行い、さらに町の内部に新たに堀を掘削し、舟運の便を活 かした町全体の他面的な利用を図ることを目的として、明暦元 (1655) 年、牧野忠成により「明暦の町割り」が実施された。こ れにより、新潟町には寺町堀 (のちの西堀) ・片原堀（のちの

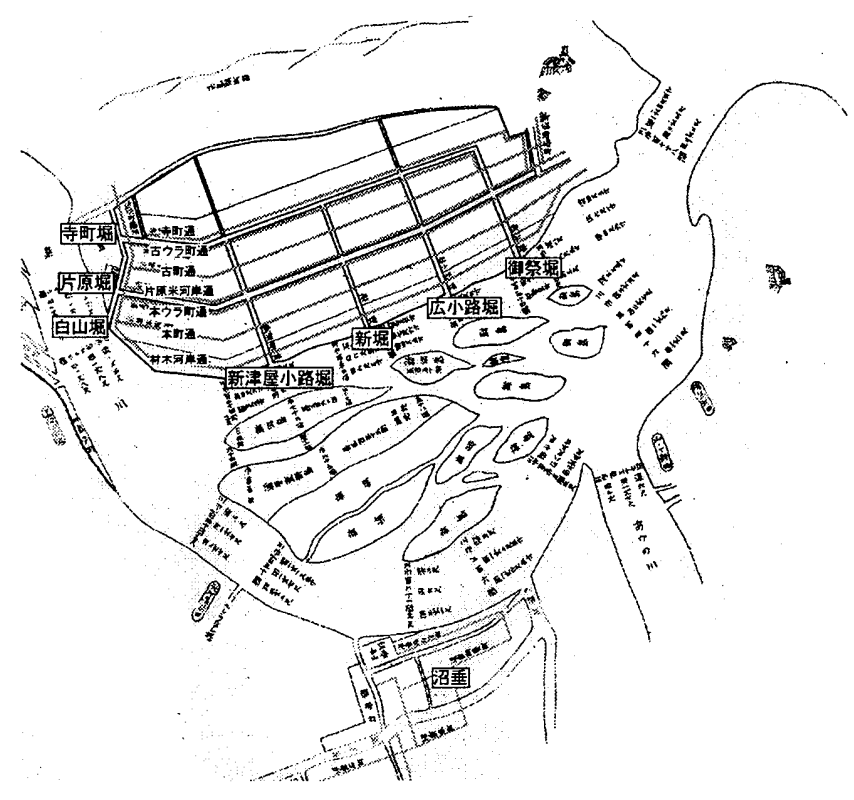

図1元禄12(1699) 年の新潟町

新渴市史上巻1「「元禄 12 年 4 月沼垂訴訟立会絵图」に筆者加筆。 当時、信浱川には数多くの中州が存在していた。新潟の町には明厏年間に整 備された 7 筋の掘が存在していることがわかる。現在、これらの堀跡は都心 部の幹線道路となっている。

東堀) - 白山堀 (のちの一番堀) - 新津屋小路堀 (のちの二番堀) 広小路堀 (のちの四番堀) - 御祭堀 (のちの五番堀) が掘削、ま たは既存の信濃川の枝川を利用して整備された。さらに明暦 3 (1658) 年には新堀（のちの三番堀）が掘られた（図 1)。この 町割りにより形成された市街地の形態はその後、基本部分はほ とんど変わらずに現在に及んでいる。

明治・大正期に入ると、明治元（1868）年の新潟港開港、明 治 5 (1872) 年の県令・楠本正隆の着任などにより新潟の町や 堀の整備が更に進むこととなる。また、それまで信濃川の中洲 であった島々が陸地とつながり、また近づいてくることにより

*1 Graduate Student, Graduate School of Eng., Hokkaido University

*2 Prof., Graduate School of Eng., Hokkaido University, Dr. Eng. 


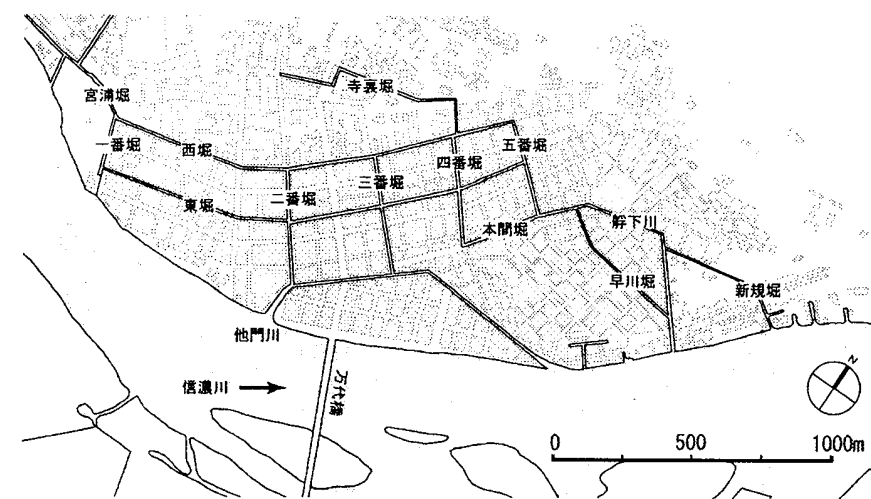

図 2大正 14（1925）年の掘割

新潟市図大正 14 年 6 月 3 版改訂より筆者作成。

表1大正13（1924）年 堀の延長と幅 新潟都市計画概要 ${ }^{2}$ 上り筆者作成。

\begin{tabular}{|c|c|c|c|}
\hline 名称 & 延長(間) & 幅(間) & 坪数(坪) \\
\hline 蔵所堀 & 946.6 & 2.5 & 2270.0 \\
\hline 宮浦堀 & 77.9 & 4.0 & 311.7 \\
\hline 二番堀 & 177.8 & 11.0 & 1956.1 \\
\hline 二番堀 & 247.0 & 4.5 & 1111.5 \\
\hline 三番堀 & 252.7 & 4.5 & 1137.2 \\
\hline 四番堀 & 224.8 & 4.3 & 966.6 \\
\hline 五番堀 & 192.4 & 4.2 & 800.1 \\
\hline 寺裏堀 & 893.2 & 3.0 & 2679.6 \\
\hline 東堀 & 925.2 & 4.0 & 3700.8 \\
\hline 西堀 & 862.3 & 4.0 & 3449.2 \\
\hline 内他門川 & 445.8 & 5.1 & 2273.6 \\
\hline 他門川 & 661.3 & 10.0 & 6613.0 \\
\hline 本間堀 & 367.2 & 0.5 & 183.5 \\
\hline 早川堀 & 385.4 & 4.0 & 1541.6 \\
\hline 艀川 & 517.0 & 5.2 & 2698.8 \\
\hline 新規堀 & 73.5 & 73.5 & 382.2 \\
\hline 計 & 7250.1 & & 32075.4 \\
\hline
\end{tabular}

(約 $13.2 \mathrm{~km})$

(約 10.6 万 $\left.\mathrm{m}^{2}\right)$
表 2 年表 (本研究関連事)

\begin{tabular}{|c|c|c|}
\hline 西暦 & 年豆 & 新潟関連の出来事 \\
\hline 1616 & 元和2 & 幕府が堀直寄を長岡へ移す \\
\hline 1617 & 元和3 & |堀直寄が新町·材木町·洲崎町の町建てを命じる \\
\hline 1618 & 元和 4 & 幕府は牧野忠成を長岡城主にする \\
\hline 1867 & 慶応3 & $\begin{array}{l}\text { イギリスなど5か国が新潟開港に同意する } \\
\text { 新潟府が新潟県となる }\end{array}$ \\
\hline 1871 & 明治4 & $\begin{array}{l}\text { 新潟県令楠本正隆が着任する } \\
\text { 新渴県が新潟町の町名を改定·制定する }\end{array}$ \\
\hline 1873 & 明治6 & 新潟運上所が新潟税関と改称する \\
\hline 1886 & 明治 19 & $\begin{array}{l}\text { 内山信太郎が万代橋の架橋工事を始める } \\
\text { 信濃川河身改修と堤防改築工事が始まる } \\
\text { 新潟区が新潟市となる。また、町村合併が実施される }\end{array}$ \\
\hline 1896 & 明治29 & $\begin{array}{l}\text { 信濃川流末改修工事が始まる } \\
\text { 新潟県全域で大水害が起こる(横田切れ·木津切れ) }\end{array}$ \\
\hline 1908 & 明治41 & 新潟市で大火が起こる。初代万代橋が焼失する \\
\hline 1909 & 明治42 & 2代目万代橋が開通する \\
\hline 1914 & 大正3 & 沼垂町が新潟市に合併する \\
\hline 1917 & 大正6 & 新潟港築港工事が始まる \\
\hline 1922 & 大正11 & 大河津分水が通水する \\
\hline 1923 & 大正12 & 新潟臨港が築港工事を始める \\
\hline 1925 & 大正14 & 新潟都市計画区域が認可される \\
\hline 1926 & 大正15 & 県営埠頭が完成する \\
\hline 1929 & 昭和4 & $\begin{array}{l}\text { 万代橋上流両岸の埋め立てエ事が始まる } \\
\text { 3代目万代橋の竣工式が挙行される }\end{array}$ \\
\hline 1931 & 昭和6 & $\begin{array}{l}\text { 万代橋下流西護岸整備工事が始まる } \\
\text { 昭和橋が開通する }\end{array}$ \\
\hline 1934 & 昭和9 & 昭和橋上流西岸の埋め立て工事が始まる \\
\hline 1937 & 昭和12 & この年、柾谷小路·東中通の道路拡幅が完成する \\
\hline 1955 & 昭和30 & $\begin{array}{l}\text { 新潟大火が発生する } \\
\text { 火災復興土地区画整理が都市計画決定される } \\
\text { この年、東掘の埋め立てが始まる }\end{array}$ \\
\hline 1956 & 昭和31 & この年から、地盤沈下が顕著となる \\
\hline 1959 & 昭和34 & この年、早川堀·御祭堀·蔵所堀が埋め立てられる \\
\hline 1962 & 昭和37 & この年、西堀の埋め立てが始まる \\
\hline 1963 & 昭和38 & この年、他門川の埋め立てが始まる \\
\hline 1964 & 昭和39 & $\begin{array}{l}\text { 新潟国体が開催される } \\
\text { 新潟地震が発生する }\end{array}$ \\
\hline 1995 & 平成7 & 「新潟市第四次総合計画」が策定される \\
\hline
\end{tabular}

際に内務省・中央方面の専門家からの“東堀は運河として盛ん に活用されており、また震災の経験から都市の運河は防災上重 要である。…'注2) との反対意見により、東堀の埋め立ては見 送られ当分現状を維持することとなる。しかし、このような計 画が持ち上がったことは交通手段が水運から陸運へ変化しつつ あったことを示し、またこれ以降、東堀以外の各堀においても 堀の浄化よりも先に埋め立てが考えられるようになるのであ る。

\section{3. 戦後の新渴と掘割}

戦後、新潟市は県都として大きく発展することとなる。人口 も昭和 25 （1950）年は約 22 万人、昭和 30 (1955) 年は約 26 万 4 千人、昭和 35 （1960）年は約 32 万人と推移していく。都心部 においては、新潟大火の発生や高度経済成長、新潟国体の開 催、新潟地震の発生などを契機に大きな変容を遂げる。そし て、モータリゼーションと掘割の機能・重要性の低下は都心部 に存在した多くの掘割の埋め立てにつながった。以下、埋め立 ての要因について個別にまとめる。

\section{3-1 自動車の普及}

昭和期に入ると自動車の増加が見られるようになる注3!。ま た、大正11（1922）年には市中心部においてバスの運行が始 まっており、路線数やバスの台数も増加していた。そのため道 


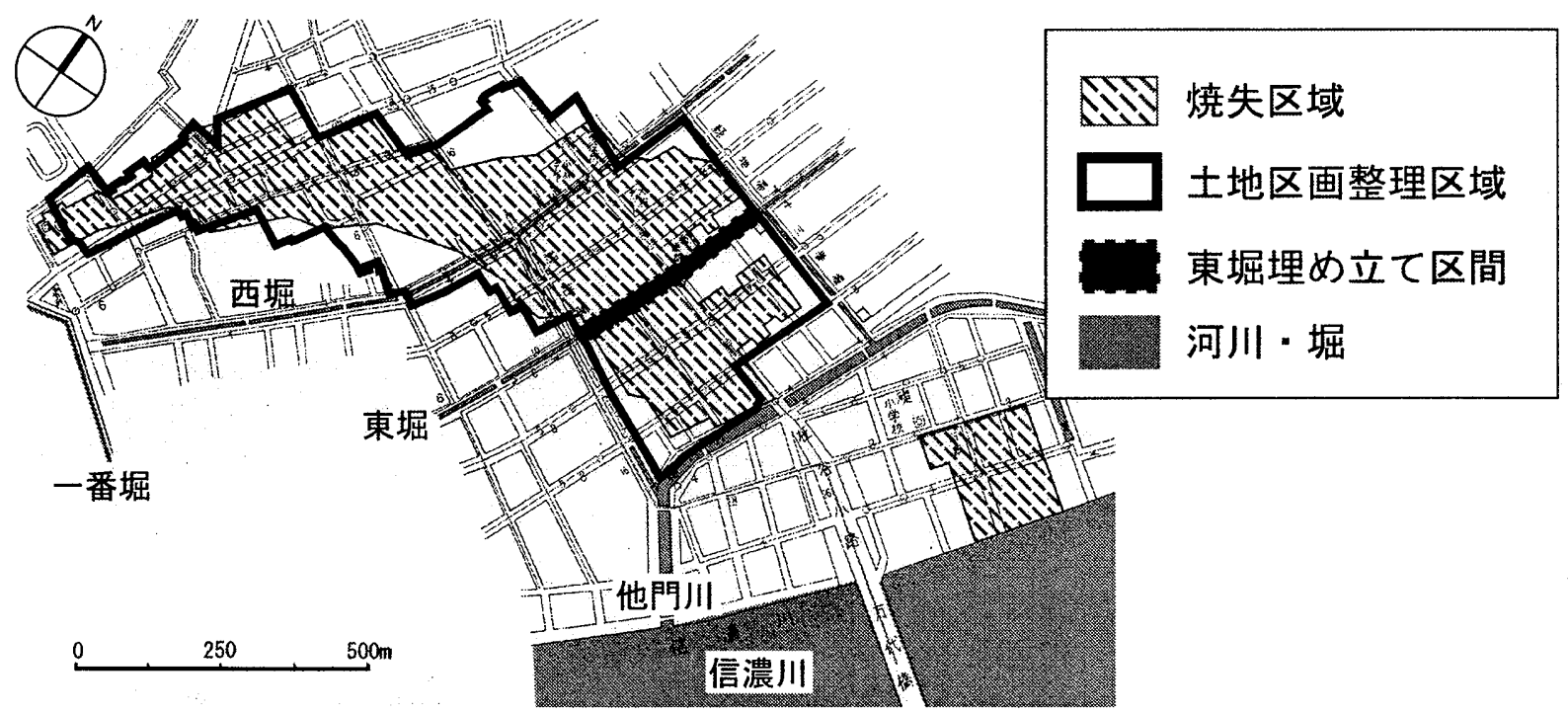

図 3 新潟大火による焼失区域と土地区画整理区域

昭和 30 年新潟大火災誌 ${ }^{9}$ 「䍜災地域附近 消防水利状況図」に筆者加筆。土地区画整理区域と掘割埋め立て区間は新潟県の土地区画整理事業還暦記念誌10) 「新潟都市計画火災復興土地区画整理＼cjkstart整理前ノ換地図」により重权た。スケールと方位は筆者が加えた。他門川を境に延焼が防がれたことがわかる。ま た、この土地区画整理により東堀の埋め立てが決定された。

路も橋も自動車交通に耐えるものに整備していく必要があっ た。昭和10（1935）年には交通量の増加よりも堀の防災上、舟 運上の役割が重視され東堀の埋め立ては見送られたが、昭和 20 〜 30 年代には交通の中心が水上から陸上へ移り、徐々に堀の水 運上の役割は失われていく。そして、交通量の問題、道路の拡 幅が無視できない問題となる。現在、かつての掘割はすべて道 路となっている。

\section{3-2 新渴大火}

昭和 30 年 10 月 1 日、市街地から出火した火は市の中心部を 焼き尽くした。この時、消火栓のポンプの故障などの諸条件が 重なり、消火活動に支障をきたした。そこで、西堀・東堀・他 門川などの自然水利を利用した消火活動が行われ、大火後、実 際に消火活動を行った消防士の多くが自然水利の重要性につい て述べている。西堀・東堀は周辺地域の消火活動に役立ち、他 門川は周辺の消火活動に加え、延焼を防ぐことにも役立った （図 3 ）。河川や堀を流れる水は水蒸気を発しているため熱気を 断ち切る効果があったとのことである。このように自然水利で
ある掘割・河川の重要性が再認識される。

大火の復興計画や土地区画整理事業では大火の教訓から、中 心市街地の不燃化、交通・防火施設の強化、墓地・公園の整備 等を中心とした計画がなされた。将来人口 50 万人を見込んでの ものでもあった。しかし、この復興計画には、西堀、東堀、他 門川、一番堀（幅員の一部）の延長の一部を埋め立て、街路又 は緑地帯とすることが含まれていた（図 3 )。

そして、東堀は昭和 31 (1956) 年 2 月に三番堀〜柾谷小路間 に排水管を埋め、幅員 $22 \mathrm{~m}$ の道路にする工事が始まり、昭和 38 (1963) 年に東堀の全ての埋め立ては完了した注4)。

他門川には木造のマーケットが張り出すように建てられてお り、これらの処理の問題があり、結局この時点では他門川の埋 め立ては行われなかった。

また、一番堀は1956（昭和 $31 ）$ 年 3 月から、大火により投げ 込まれた瓦碩を整理して堀幅を縮め、新たに護岸を設けて道幅 を $17.5 \mathrm{~m}$ に広げた。この時の埋め立てにより堀幅は $5 \mathrm{~m}$ 程度に なったと推測される。その後、1964（昭和 39）年に残った堀幅

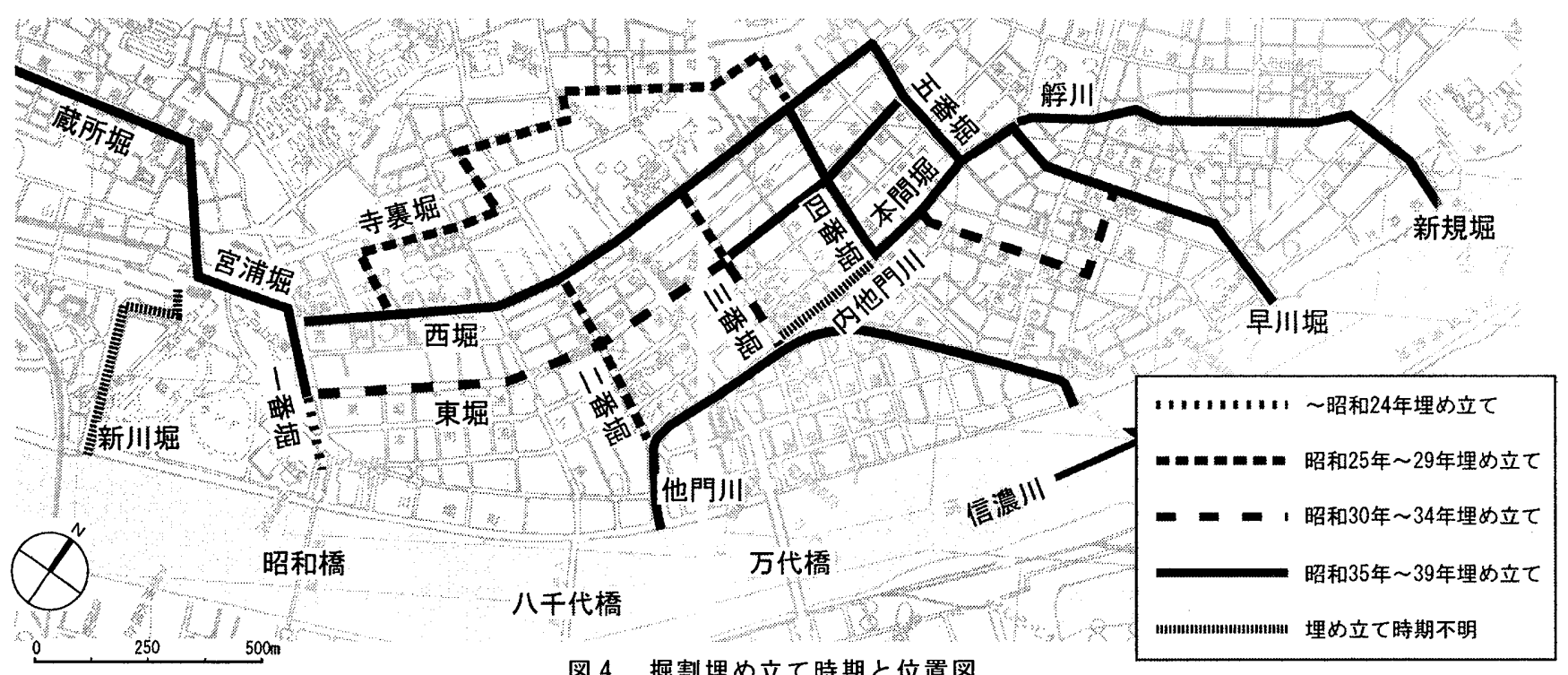

図 4 掘割埋め立て時期と位置図

文献 34 4) 57 6) 7) 8) による調查と昭和 $33 、 34 、 35 、 39 、 42 、 51$ 年の新潟市住宅地図の比較により筆者作成。 


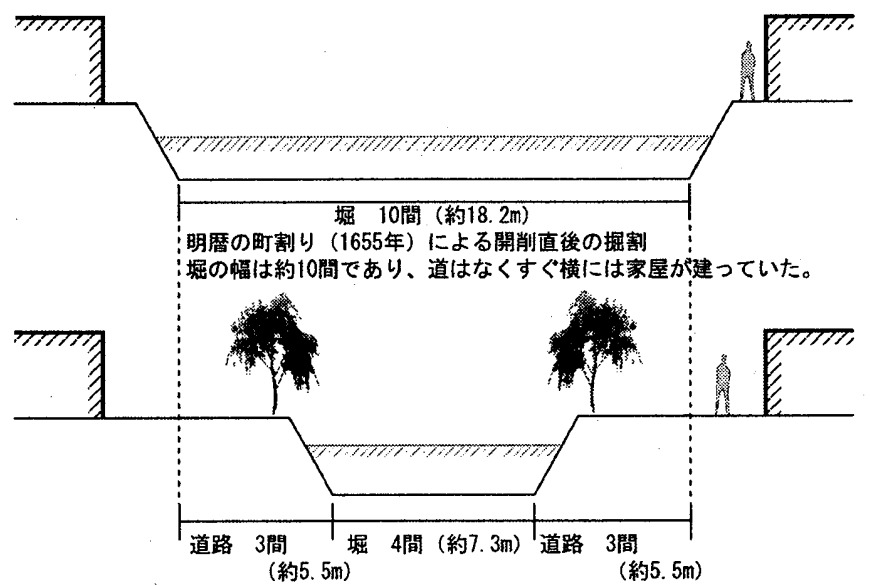

孪保年間（1684～88年）頃までに両岸が翮3間ずつ埋め立てられ道路となった。 挪は正德年間 $(1711 〜 16)$ に植えられたという

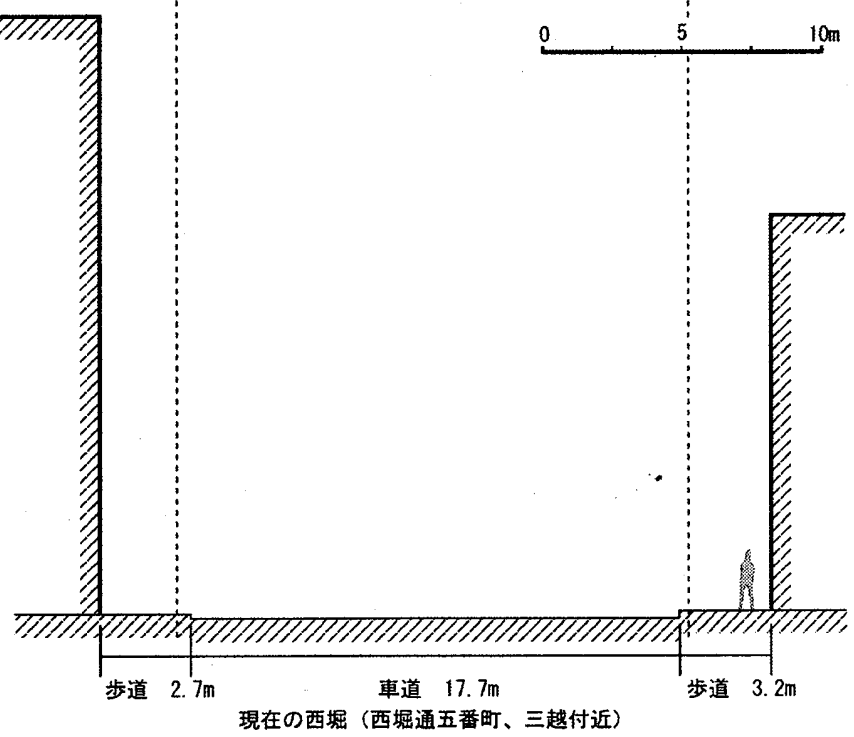

図 5 西堀の断面比較

文献4) 5) 13)、新潟市道路台帳を基に筆者作成

現在の道路の幅員とかっての堀の幅員はほぼ同じである。しかし、次ページ の写真 1,2 からも分かるように、堀が存在していた頃の水の都としての情緒 は完全に失われてしまった。

も埋め立てられ道路となる。

このように、復興計画では消防関係者が防災の観点から掘割 の維持、水深を梁くするなどの整備が必要であると主張する 中、逆に東堀などが実際に埋め立てられていくのである。

\section{3-3 地盤沈下}

新潟市の地盤沈下は昭和 30 年頃から目に見えて速度を増し その沈下量も大きくなっていった。中でも信濃川河口、港湾地 帯が最も大きく年間沈下量は最大 $50 \mathrm{~cm}$ 量しも達していた。その ため、当時堀に水を流すためには白山浦の揚水機で信濃川の水 を汲み上げ、早川堀から信濃川への出口でポンプによる排水が 必要であった。しかし、そのポンプも昭和 30 年代になると止ま りがちであったということであり、堀の水は流れにくく不衛生 なものになっていったことがわかる。

この急速な地盤沈下の主原因は昭和 34（1959）年 6 月及び昭 和 35 (1960) 年 6 月に科学技術庁の調査により、“ガス採取に 伴う地下水の急激、かつ大量の汲み上げによる。”11) とされた。 科学技術庁の発表以前に運輸省・県・市の調査により地下水の 急激な汲み上げが原因ではないかとされていたため、昭和 34 (1959) 年から自主規制を含めた、水溶性天然ガス採取規制が
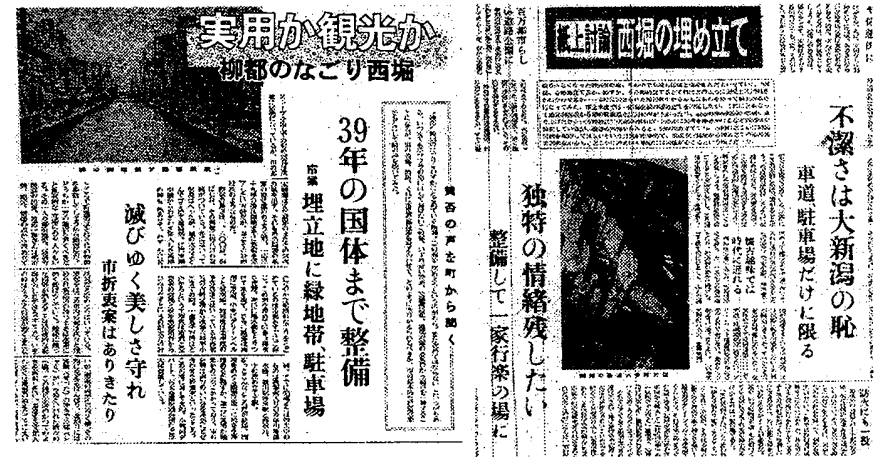

図 6 西堀埋め立てに関する記事

左/昭和 35 年新渴日報 実用か钼光か、39 年の国体まで整碏、滅びゆく美 しさを守れ、など西堀の跡地利用に関する記事。

右/昭和 36 年新渴日報紙上討論西堀の埋め立て、不潔さは大新潟の恥、独 特の情緒残したい、一部文化財に残す、など西堀埋め立てに対する賛成論、 反対論、折衰論が見られる。

行われるようになった。さらに、海岸沿い・信濃川沿いに堤防・ パラペットが市街地を囲うように造られ、雨や家庭排水などを 処理するために排水路・ポンプ場（蔵所堀ポンプ場、他門川ポ ンプ場、縁町ポンプ場など）が整備された。そしてこれら排水 路やポンプ場の整備により掘割の排水路としての役割は徐々に 失われていくこととなる。

\section{3-4 新渴国体}

昭和 39 年 (1964) の新潟国体は都市のインフラ整備の契機と なった。道路の拡張・舖装、八千代橋の架橋、昭和大橋の架け 替えなど、都市施設の整備や、市民の生活環境の整備などが国 体開催を目標に急速に進められた。そして、生活用水・排水路・ 物資輸送の役割が薄れた市内の堀は町の美化、近代化を目的々 し、すべて埋め立てられることとなった（図 4)。

\section{3-5 西堀の埋め立て}

数多く存在した掘割の中でも町の中心部を流れる西堀は幹線 の堀であり、水の都新潟の大きなシンボルの一つでもあった。 そこで西堀の埋め立ての経緯について詳しく見ることとする。

西堀は明暦元 $(1655)$ 年の明暦の町割りにより寺町堀として ほほ現在の西堀通の位置（西堀通一番町〜同十番町）に信濃川 （当時は大川と呼ばれていた）から直接流れてきていた枝川を 利用して整備されたものである。当初の寺町堀の両岸には道が 付いておらず、家屋が建ち並んでいた。堀の幅は 10 間（約 $18.2 \mathrm{~m}$ ) であった。その後、賁享年間（1684〜88 年）までに両岸が 3 間 ずつ（約 $5.5 \mathrm{~m} ）$ 埋め立てられ道路となった。堀の幅は 4 間（約 $7.3 \mathrm{~m}$ ）となったことになる（図 5 )。

その後も西堀は市内の排水、舟運上、防災上大きな役割を果 たし、堀の水を利用しての洗濯や飲み水としても用いられもし た。そのため、昭和 2（1927）年の白山浦のポンプによる通水 の確保など積極的な整備が行われてきた。また、周辺住民、町 内会の西堀美化に対する意識も高く、昭和 8（1933）年には周 辺住民の費用負担により桜と柳と水による西堀の美化が行われ る。しかし、戦時中は他の堀同様、維持管理が行われることが なく、戦後になるとポンプも停止となり地盤沈下の影響もあっ て生活用水がたまり悪臭を放つようになっていった。

昭和 30 年の新潟大火の発生に続き、昭和 35 (1960) 年に昭 和 39 年の新潟国体開催が決定すると、他の堀と同様に西堀にお いても本格的な埋め立ての議論が始まる。しかし、西堀が最後 まで埋め立てられず過去の姿・情緒を残していたことなどの理 由により、他の堀がほとんど反对意見もなく埋め立てられてい くのに対し、西堀の埋め立てに対しては、存続の意見があがっ 


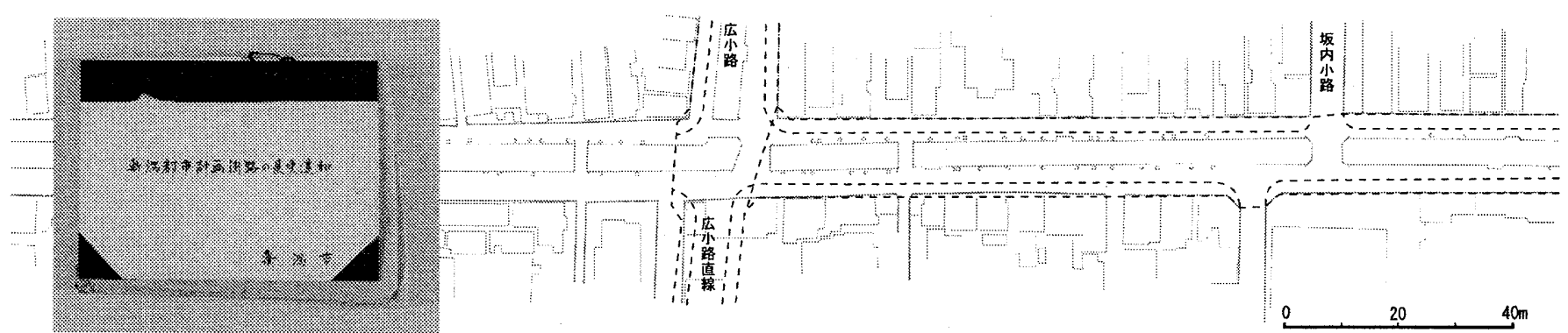

図 7 西堀の都市計画街路決定時の様子注(0)

新潟県新潟都市計画街路の変更及び追加について 昭和 38 年 ${ }^{13}$ （国立公文書館蔵）より 図面柱青焼き図面を基に筆者作成。

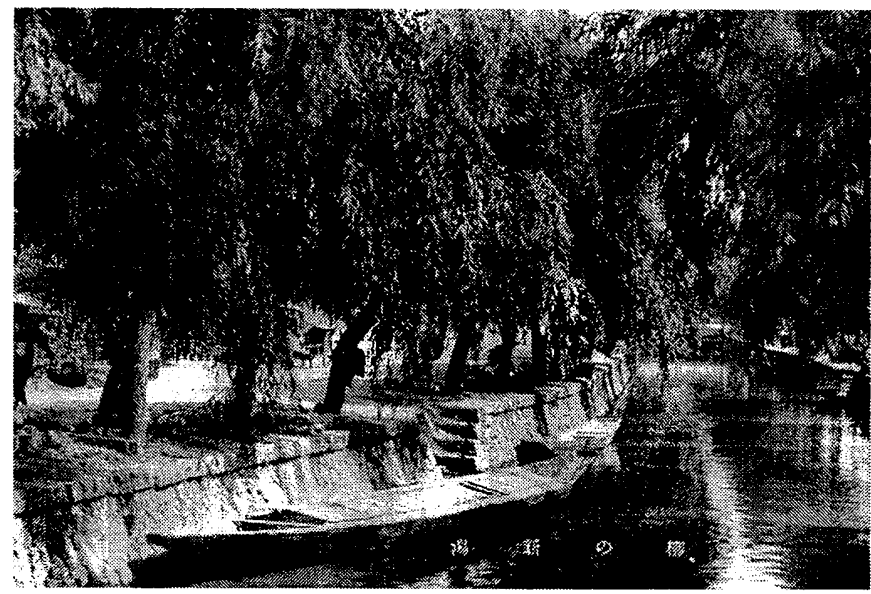

写真 1 大正から昭和初期の西堀

新舄市：新潟歷史双書 5 新潟の堀と橋4〉より転載。

石垣の護岸が整っていること、堀の水が清潔に保たれていることからしっか りと維持管理が行われていたことがわかる。

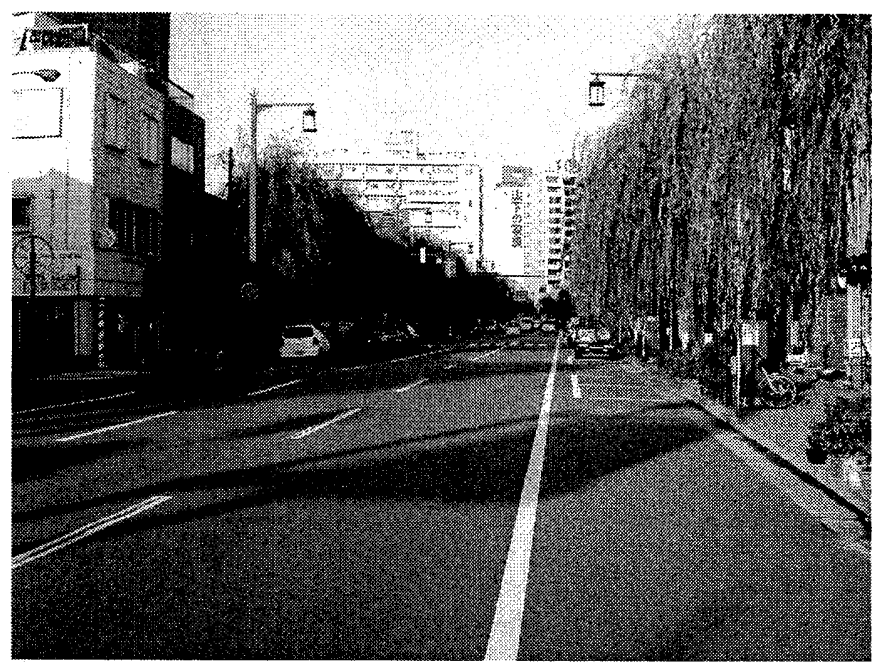

写真 2 現在の西堀通

平成 14 年 9 月 筆者撮影。

現在の西堀は新渴の都心部における幹線道路であり、一方通行ではあるが、 片側に駐車帯がある幅員の広い道路である。柳の並木は埋め立て後に植栽さ れたものである。

た。当時の新潟日報の記事を参考に西堀の埋め立てまでの経緯 を見ることとする（図 6 )。

西堀埋め立てまでの大きな流れを見ると、基本的に三つの考 え方があることが分かる。一つ目は、将来の交通量問題を根拠 とし西堀を完全に埋め立てその土地の全てを道路とする意見。

この意見の中では、将来歩行者専用道となることが計画されて

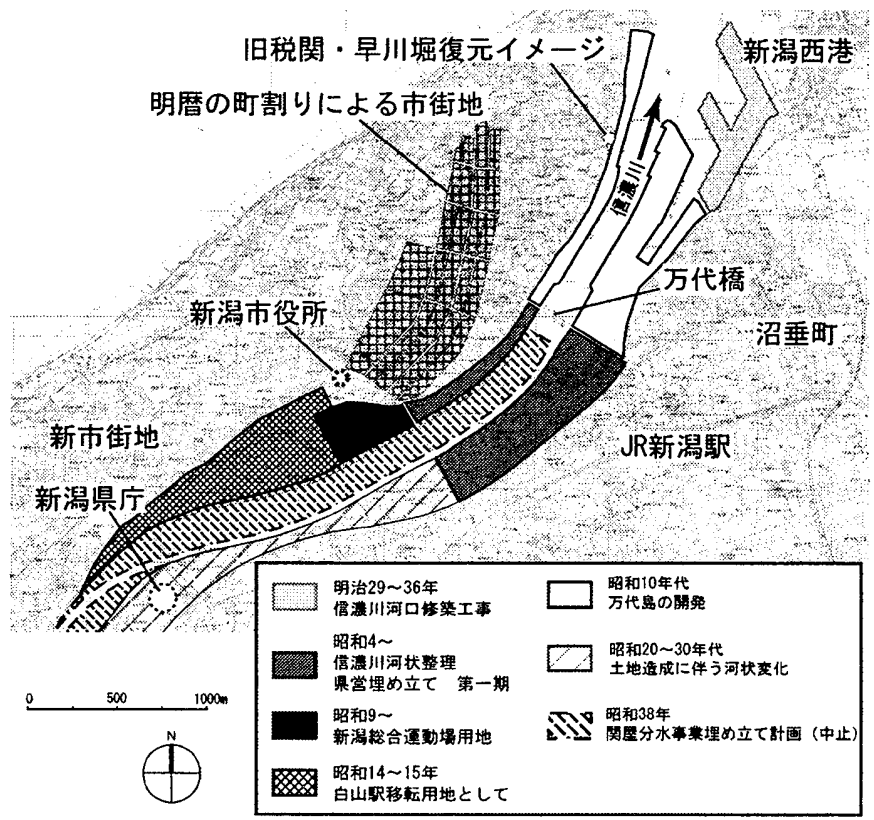

図 8 信濃川の埋め立て箇所

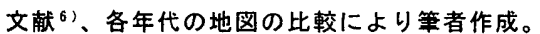

信浱川の埋め立てにより広大な土地を造成したことがわかる。関屋分水事業 埋め立て計画は新渴地震の発生などのにより中止となった。

いた古町や、関屋分水完成後に出来上がるとされていた信濃川 の埋め立て地において水の都の観光資源の整備を行うことも述 ベられている。

二つ目は観光、情緒、防災の観点から西堀の埋め立てに完全 に反対する意見。この意見のなかでは堀の維持管理を積極的に 行いかつての清流と情緒を取り戻したい、交通量の問題は東堀 埋め立て後の道路で解決できるとしている。また、新潟の今後 の発展は東新潟中心に進んでいくから西新潟の自動車の数はそ れほど増加しないのではないかと述べられている。

三つ目は折束案というべきものであり、西堀の埋め立ては実 施するがその後の道路整備に関しては緑地帯を設忛るなどの措 置を行うというものであった。

当時、西堀埋め立てに関しては紙上討論が行われるなど市民 の関心は高く、様々な意見が出されたが、地元住民としては埋 め立てを望む意見の方が多かったようであり陳情・請願もなさ

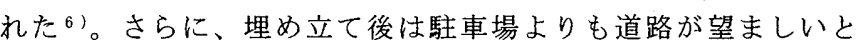
いう地元住民の意見が新開記事にある（図6）。

このような状況の中で新潟市は、下水道の整備によって、1，2 年中に西堀の下水溝としての役割は終わる、西新潟下手一帯か ら中心に通じる交通量をさばくには東堀幹線道路だけでは不足 が予想される、西堀の美化は難しく水面を残さずとも緑地帯の 
整備などによって美化は図られる、また信濃川の埋め立て地の 整備注5)を行うから西堀の美化は必要ないという理由により西 堀全線の埋め立てを昭和 36（1961）年に内定する注6)。

また、昭和 37 (1962) 年 2 月に新潟日報による市議会議員に 対するアンケートの結果も西堀埋め立てに関して賛成 33 人、反 対 8 人、折哀案 1 人という結果に終わり、西堀の埋め立てが具 体化していくこととなる注7。

昭和 $37(1962)$ 年 9 月、市議会は継続審議になっていた西堀 埋め立て促進を求める陳情を“国体をひかえ、早急に整備の具 体的方策を樹立願う意味において’ 全員一致で採択した。同年 12 月から西堀の排水管敷設工事が始まり、堀幅の半分が埋まっ た。昭和 38 （1963）年度には、埋めたままになっていた跡地を 道路にする工事と共に、6 月には全面的な埋め立てが始まり、国 体直前の昭和 39 （1964）年 5 月に埋め立てが完了した。

昭和 38 （1963）年には都市計画街路西堀通線が都市計画決定 されている。新舄計画街路変更及び追加についての資料注8)に 含まれている理由書には新潟市都心部の交通量の増加が述べら れている注9（図 7 ）。この資料より埋め立て直後の西堀の断面も 見ることができるが、現在の断面とほぼ変わらないものであ り、将来の交通量の増加を考え、車道と歩道のみのもので緑地 帯などの構想は実現しなかった。

\section{4.信濃川の埋め立て}

新潟の港町としての発展の要となった新潟港は信濃川の河口 港であり、掘割もまた信濃川の水運の便を町の中にまで引き込 む為に造られたものである。また、信濃川の河道の変化による 町の移転や洪水による被害など新舄の町は古くから信濃川の影 響を強く受け、また活用してきた。しかし、昭和初期〜 30 年代 の間に川幅約 $700 \mathrm{~m}$ あった信濃川はその川幅の約 3 分の 2 が埋め 立てられてしまう（図 8 )。

昭和初期、新潟市は無秩序な都市化と、それに伴う住宅難と いう問題を抱えていた。また、市域の中心部を流れる川幅約 $700 \mathrm{~m}$ の信濃川により市域が二分され、発展の妨げとなってい た。当時の技術ではこの大河川に幅の広い橋梁を架けることは できなかった。そこで大河津分水の完成により水量の安定した 信濃川の両岸を埋め立て、川幅を狭め、中心市街地に新たなる 土地と、大きな橋を架ける計画を実施する注11)。

この計画は予定通りには進まなかったが、昭和 30 年代までに は計画区域の埋め立てが完了し、埋め立て地の大部分は民間企 業や個人に払い下げられた。川幅は約 $270 \mathrm{~m}$ となった。この時、 埋め立て地を公園緑地、観光資源として整備するといった意識 は無かったようである。

\section{5.まとめ}

新潟の掘割は江戸時代に開削され明治・大正期の全盛期には 積極的な利用、整備が行われていた。信濃川と共に水の都・新 潟のシンボルであった。

昭和期にモータリゼーション、新潟大火、地盤沈下、国体の 開催、新潟地震などを契機に都心部は近代化を目指し整備が進 む。日本が高度経済成長を遂げる中で新舄において水の都の情 緒と特色の維持を望む声は、近代化を求める意見に押し切ら れ、掘割、信濃川の埋め立てが行われる。

新潟の掘割が埋め立てられた理由を以下にまとめる。

1）自動車や鉄道の発達に伴い、信濃川や掘割による水運の重 要性が低下し、交通網の整備（道路の拡幅）が必要になった。 2 ）地盤沈下などにより堀の水が流れにくくなり、衛生上の問 題が生じた。そのため排水路やポンプの整備が進み、掘割の排 水路としての役割が失われた。
3 ）戦時中に整備が行われず、放置されていた掘割の整備には 多額の費用と時間が必要であり、新潟国体の開催も決定し短期 間の内に解決しなければならない問題であった。

高度経済成長期に特色が失われてしまった都市は他にも数多 く存在する。しかし近年、道路や街路に対して柔軟な発想がな されるようになり、歴史や風土を活かした再開発も行われるよ うになってきた。また道路を生活空間としてとらえ歩行者を意 識した道路の事例なども数多く見られるようになった。昭和 30 年代に水運の要・排水溝の役割を失い、衛生上の問題から埋め 立てられてしまった掘割、そして信濃川は、今後魅力ある都市 空間の形成という役割を担って再生される心゙きではないだろう か。市としては水の都としてのまちづくりを「新潟市第四次総 合計画」の中で明記したが、掘割の再生についての明確な記述 は見られない。今後、市議会をはじめ、世論がどのように動い ていくのかに注目したい。

掘割再生の具体的な手法・可能性については考察が不十分で あるため、今後の研究課題とするが、都市計画の地方分権化が 進む現在が本格的な再生を検討する時期ではないだろうか。

注䣋

注 1）新潟市都市計画課、新潟市歴史文化課、新潟市土木部総務課、国土交 通省北陸地方整備局河川部

注 2）新潟毎日新聞 昭和 10 年 5 月 25 日より引用

注 3）新潟市の自動車は大正 7（1918）年には 2 台、昭和元（1925）年には 87 台、昭和 $3(1927)$ 年には 186 台となる。

注 4）昭和 $31 （ 1956 ）$ 年 2 月に三番堀〜柾谷小路間に排水管を埋め、幅員 $22 \mathrm{~m}$ の道路にする工事が始まり、続いて柾谷小路〜新津屋小路間の東堀も埋めら れた。昭和 32 (1957) 年 9 月には新津屋小路〜鍛冶小路閒の埋め立てが始 まり、翌年の1 月には道路之なった。鍛冶小路〜一番堀通間も昭和 34 (1959) 年中に埋め立てが終わり、昭和 $35(1960)$ 年には三番堀から下の八・九番 町内の埋め立てに取り掛かった。そして昭和 38 (1963) 年に東堀の全ての 埋め立ては完了した。

注 5) 当時信濃川を大幅に埋め立てる計画があったが、新潟地震の発生など によりこの計画は中止となった。

注6）新潟日報 昭和 36 年 1 月 15 日より

注 7）新潟日報 昭和 37 年 2 月 1 日、2 月 2 日、2 月 3 日より

注 8 ）国立公文書館蔵。新潟県、新潟市には保管されていない。

注 9）“新潟市都心部の交通量の增加は芸だしく、昭和 36 年交通量調查に於 いては、昭和 33 年調查時の約 1.8 倍と增加し、又市内自動車登録台数に於 いては昭和 31 年の 6,900 台に対し、昭和 36 年には 16,460 台と約 2.4 倍の増 加を示し今後益々增加の䞻勢にあるので、将来交通量に対処するため、都心 部に 2 等大路第 1 類第 3 号線のほか一路線を追加し、…という内容。

注 10 ）黒と赤で描かれた青焼き図面のため白黒の複写では不明確になるた め原図の黑線を実線、赤線を点線とし、筆者が図面の一部をトレースした。 黒線が当時の現状、赤線が都市計画道路の計画を示すもの。

注 11 ） 県営信濃川埋め立て工事として第一期埋め立ては万代橋から県議会 議事堂（現県政記念館）までの区間。第二期は白山堀上流加ら団九郎まで、 第三期は団九郎上流から都市計面区域までとなっていた。

\section{参考文献}

1）新潟市：新潟市史上巻 1934 年

2) 新潟都市計画概要 新潟市 1924 年頃奥付なし

3）新潟市：新潟市史 通史編 3 近代（上）1996年

4) 新潟市: 新潟歴史双書 5 新潟の堀と橋 2001 年

5）笹川勇吉著：新潟わが街 柳と堀 1986 年

6）新潟市：新潟市政進展史第 1 巻 4 巻 $1955 、 57 、 68 、 71$ 年

7）新潟日報社：新潟日報 $1960 \sim 64$ 年

8）新潟市：新潟市合併市町村の歴史 基嘫凟料編 $5 \sim 9 \quad$ 1982、83、84、85、 86 年

9 ）新潟大火災誌編纂委員会：昭和 30 年新潟大火災誌 1959 年

10）新潟県：新潟県の土地区画整理事業還暦記念誌 1989 年

11）新潟県、新潟市：新潟の地盤沈下 1961 年

12）小村 式編著：わが町の歴史・新潟 1979 年

13 ）新潟県新潟都市計画街路の変更及び追加について（昭和 38 年建設省告 示第1105 号) 国立公文書館蔵 1963 年

14）新潟市第四次総合計画 新潟市 1995 年

[2003年 4 月18日原稿受理２003年 7 月29日採用決定］ 